\title{
KEPUTUSAN PEMBELIAN DALAM MEMEDIASI GREEN PROMOTION DAN GREEN PRICE TERHADAP KEPUASAN KONSUMEN
}

\author{
Dian Palupi \\ Sekolah Tinggi Ilmu Ekonomi Indonesia (STIESIA) Surabaya, dianpalupi@stiesia.ac.id
}

\begin{abstract}
ABSRAK
Penelitian ini bertujuan untuk menguji promosi ramah lingkungan (green promotion) dan harga dari produk ramah lingkungan terhadap kepuasan konsumen serta meneliti keputusan pembelian sebagai variabel yang memediasi promosi dan harga produk ramah lingkungan terhadap kepuasan konsumen. Sampel penelitian ini berjumlah total 135 orang mahasiswa. Sampel diambil dengan metode accidental sampling. Hasil penelitian ini menunjukkan bahwa bahwa green promotion yang berwawasan lingkungan memiliki pengaruh langsung terhadap keputusan pembelian. Harga premium berpengaruh positif terhadap keputusan pembelian. Keputusan pembelian memiliki pengaruh secara signifikan terhadap kepuasan konsumen pada produk ramah lingkungan. Keputusan pembelian terbukti sebagai variabel yang memediasi pengaruh promosi dan harga dari produk ramah lingkungan terhadap kepuasan pembelian
\end{abstract}

Kata kunci : green promotion, green price, kepuasan konsumen, keputusan pembelian

\begin{abstract}
This study aims to examine the promotion of environmentally friendly (green promotion) and the price of environmentally friendly products on consumer satisfaction and examine purchasing decisions as a variable that mediates promotions and prices of environmentally friendly products on consumer satisfaction. The sample of this study totaled 135 students. Samples were taken by accidental sampling method. The results of this study indicate that green environmental promotion has a direct influence on purchasing decisions. Premium prices have a positive effect on purchasing decisions. Purchasing decisions have a significant influence on customer satisfaction on environmentally friendly products. Purchasing decisions are proven as variables that mediate the influence of promotions and prices of environmentally friendly products on purchase satisfaction
\end{abstract}

Keywords : : green promotion, green price, customer satisfaction, buying decision

Naskah diterima : 19-03-2020, Naskah dipublikasikan : 31-03-2020

\section{PENDAHULUAN}

Kesadaran konsumen untuk mentransformasi pola hidupnya menjadi pola hidup sehat dan kepekaan terhadap pelestarian lingkungan hidup berdampak terhadap pemilihan produk yang akan dibeli. Menurut data dari Catalyze Sustainability Communications (www.hijauku.com diterbitkan 13 July 2011), keluarga dengan pendapatan tahunan mencapai US $\$ 5,000-U S \$ 15,000$, yang masuk dalam katagori pendapatan kelas menengah di Indonesia, diperkirakan akan tumbuh dari 36\% pada 2010 menjadi lebih dari 58\% pada 2020. Seiring kenaikan pendapatan masyarakat, pola konsumsi dan gaya hidup mengalami perubahan Adalah sektor ritel yang dimungkinkan tumbuh subur seiring peningkatan jumlah pendapatan masyarakat. Hal ini menyebabkan adanya dampak positif maupun negatif pada lingkungan, Di 
satu sisi, dampak negatif yang muncul adalah adanya pemborosan energi dan sisa sampah yang semakin besar. Namun demikian, di sisi lainnya, peningkatan pendapatan diharapkan akan mampu meningkatkan tingkat pendidikan masyarakat di Indonesia sehingga pemahaman terhadap lingkungan akan semakin tinggi dan gaya hidup serta kemampuan membeli produk ramah lingkungan semakin tinggi.

Dampak langsung yang dirasakan konsumen terhadap perubahan lingkungan seperti kondisi cuaca ekstrim, kebakaran hutan, dampak kesehatan dari penggunaan bahan baku yang tidak ramah lingkungan, terganggunya ekosistem yang diakibatkan oleh berkurangnya lahan pertanian dan eksploitasi makhluk hidup lain serta kepedulian mereka terhadap keberlanjutan lingkungan juga menyebabkan konsumen mulai beralih menjadi green customer dan mencari perusahaan, produk dan jasa yang ramah lingkungan (Mas'od \& Chin, 2014 dalam Cruz dan Prabawani , 2017). Market share produk ramah lingkungan diestimasi kurang dari $4 \%$ di seluruh dunia, namun negara berkembang memiliki kontribusi terhadap peningkatan level konsumsi dan efek lingkungan (Ritter, Borchardt, Vaccaro, \& Pereira, 2015 dalam widodo, et.al : 2015). Selain konsumen, perusahaan juga bereaksi sebagai bentuk apresiasi terhadap lingkungan hidup, sehingga banyak perusahaan menjadi perusahaan hijau atau berbasis lingkungan.

Data yang dilansir oleh Kementerian Lingkungan Hidup dan Kehutanan dalam website resminya, www.kemenlhk.go.id mengungkapkan bahwa Indonesia adalah peringkat kedua di dunia penghasil sampah plastik ke Laut setelah Tiongkok. Selain itu juga sampah plastik dari 100 toko/gerai anggota Asosiasi Pengusaha Ritel Indonesia APRINDO selama 1 tahun akan menghasilkan 10,95 juta lembar sampah kantong plastik yang berarti sama dengan luasan 65,7 Ha kantong plastik atau sekitar 60 kali luas lapangan sepakbola. Padahal kantong plastik sendiri membutuhkan waktu antara 50-100 tahun untuk menguraikan (http://nationalgeographic.co.id, tanggal 23 Januari 2016). Hal ini menjadi salah satu pemerintah

Hasil survei WWF-Indonesia dan Nielsen survey tahun 2017 menunjukkan sebanyak $63 \%$ konsumen Indonesia bersedia mengkonsumsi produk ramah lingkungan dengan harga yang lebih tinggi. Hal ini menunjukkan peningkatan kesadaran konsumen yang signifikan terhadap konsumsi produk ramah lingkungan dan mengindikasikan kesiapan pasar domestik menyerap produk-produk yang diproduksi secara berkelanjutan. Survei persepsi konsumen dilakukan WWF dan Nielsen terhadap 916 responden di Jakarta, Medan, Surabaya, Denpasar, dan Makassar yang mewakili konsumen kelas menengah ke atas berusia 15-45 tahun. Survei dilakukan di bulan Juni hingga Juli 2017. (http://www.hijauku.com, 18 September 2017).

Perubahan pola hidup masyarakat tersebut menyebabkan para pebisnis yang peka mulai merubah strategi pemasarannya.

Kesadaran akan pola konsumsi manusia yang membahayakan lingkungan harus dibarengi dengan perubahan pola pikir manusia terhadap lingkungan sekitarnya, dalam hal ini cara pandang manusia dengan alam sekitarnya. Selama ini manusia memperlakukan lingkungannya semata-mata berlandaskan pada ideologi antroposentrisme melalui praktek industrialisasi sebagai upaya pemenuhan pasar yang mengedepankan pertumbuhan.

Cara pandang antroposentrisme mempengaruhi manusia untuk mengeksploitasi alam dan lingkungan atas nama pembangunan. Berdasarkan pada ideologi antroposentrisme juga menjadikan kekuatan pikir manusia tumbuh melahirkan teknologi dan industri yang maha dahsyat, namun di sisi lain mengorbankan alam. Alam dan lingkungan tidak lagi sekedar untuk memenuhi kebutuhan konsumsi manusia, namun sudah mengarah pada pemuasan hidup. Manusia yang dulunya di jaman purba memanfaatkan alam dan lingkungannya untuk pemenuhan kebutuhan "fungsional", kebutuhan biologis, namun dengan ideologi antroposentrisme ini bergeser untuk memenuhi kebutuhan "sosial". (sumber :www.bpn.go.id)

Ada beberapa alasan baik dari luar maupun dalam perusahaan yang mendasari mengapa terjadi perubahan orientasi bisnis sehingga perusahaan bertransformasi menjadi go green company 
(Polonsky dan Rosenberg, 2001 dalam Setiyaningrum, et.al (2015, 313), yaitu untuk memenuhi kebutuhan dan permintaan dari konsumen, kompetitor telah melakukan tindakan go green, permintaan dari saluran atau pemasok untuk memodifikasi inputnya, efisiensi sumber daya melalui penerapan tindakan ramah lingkungan dan sebagai filosofi bisnis.

Perubahan orientasi bisnis juga menimbulkan perubahan dalam alat-alat pemasaran ramah lingkungan, seperti label ramah lingkungan (eco label), merek yang ramah lingkungan (eco brand), sampai dengan iklan dengan tema lingkungan. Hal ini memunculkan penggunaan istilah seperti "eco" dan "green" secara meluas dalam kehidupan masyarakat baik oleh produsen ataupun konsumen. Dengan perusahaan memunculkan label, merek dan iklan ramah lingkungan, bisa menjadi sinyal munculnya komitmen dan kesadaran terhadap pencegahan kerusakan lingkungan sebagai dampak dari kegiatan yang dilakukan oleh manusia (www.bpn.go.id). Berdasarkan uraian di atas, maka dapat dirumuskan tujuan penelitian ini, yaitu untuk mengetahui bagaimana keputusan pembelian memediasi green promotion dan green price terhadap kepuasan konsumen.

\section{KAJIAN LITERATUR Pemasaran Hijau}

Menurut Lampe dan Gazsa, 1995 dalam Setiyaningrum, et.al., (2015: 309) pemasaran ramah lingkungan adalah kegiatan pemasaran yang didasarkan kepada tanggapan atas lingkungan, mulai dari perancangan, produksi, pengemasan, pelabelan, penggunaan dan pembuangan barang atau jasa. Perusahaan yang melakukan pemasaran ramah lingkungan mengetengahkan isu-isu lingkungan sebagai alat dalam memasarkan produknya. Sedangkan definisi pemasaran ramah lingkungan menurut American Marketing Association adalah "green marketing is the marketing of products that are presumed to be environmentally safe" artinya bahwa pemasaran hijau (green marketing) adalah pemasaran produk yang dianggap aman bagi lingkungan (dalam Bukhari (2011).

Dahlstrom (2011:5) dalam Savitri, et.al (2016) menyatakan bahwa green marketing merupakan "the study of all efforts to consume, produce, distribute, promote, package, and reclaim products in a manner that is sensitive or responsive to ecological concerns.". Artinya studi tentang semua upaya untuk mengkonsumsi, memproduksi, mendistribusikan, mempromosikan, mengemas, dan mengklaim produk dengan cara merespon terhadap kepedulian lingkungan. Green marketing tidak hanya dilihat dari aktifitas pemasaran dan komponen maupun karakteristik produk yang dihasilkan saja, namun juga ditinjau dari proses dan teknik produksinya.

Menurut Solaiman, et.al (2015), pemimpin pasar mempersepsikan bahwa pemasaran ramah lingkungan menguntungkan, Riset dari Gallup oll of Fortune 500 executives menunjukkan bahwa sebanyak 58\% konsumennya bersedia membayar lebih untuk produk dan komponen daur ulang (Schorsch, 1990) dalam Solaiman (2015). Penelitian yang dilakukan oleh Abzari, et.al (2013) menunjukkan bahwa terdapat pengaruh signifikan dan positif antara bauran pemasaran ramah lingkungan terhadap peningkatan pangsa pasar.

Karna dan Juslin (2001) dalam Nursanti dan Melisa (2011) mengatakan bahwa green advertising adalah periklanan yang berwawasan lingkungan. Termasuk di dalamnya informasi yang menyatakan kepedulian terhadap lingkungan seperti tanda. (1) recycled, biasanya ditandai dengan simbol anak panah yang melingkar, (2) ozone-friendly, produk yang digunakan tidak mengancam lapisan ozon. Biasanya klaim dari produk-produk lemari es; (3) biodegradable, produk tidak mencemari udara, angin, dan air; (4) phosphatefree, produk terbebas dari phosphate yang dapat mencemari lingkungan, khususnya air; (5) organic, produk telah menggunakan zat organic tertentu untuk mengganti zat-zat kimia atau zat lainnya yang dapat mengganggu kesehatan dan keselamatan konsumen; (6) fat-free, produk bebas lemak seperti produk makanan ringan, permen; (7) non-toxic, produk tidak mengandung zat beracun yang 
dapat mengancam keselamatan konsumen. Digunakan zat-zat yang aman bagi kesehatan untuk mengganti bahan kimiawi; (8) cruelty free. Produk dibuat tidak melalui percobaan terhadap hewan, seperti produk obat-obatan maupun kosmetik.

\section{Bauran Pemasaran Hijau}

Dalam dunia marketing, penerapan strategi marketing hijau (green marketing) yang dimasukkan dalam bauran pemasaran disebut sebagai green marketing mix (bauran pemasaran hijau). Bauran pemasaran hijau adalah kombinasi dari produk / jasa hijau (green product or service) dengan harga hijau green price / saluran distribusi dan promosi strategis

Elemen dari Bauran Pemasaran Hijau (green marketing mix) menurut Al-Bakry, 2007 dalam Hashem (2011)

1. Produk Hijau (ramah lingkungan)

adalah produk yang merespon kebutuhan dan persyaratan lingkungan. Seiring kebutuhan konsumen yang berubah, adalah penting bagi perusahaan untuk memperbaiki dan mengembangkan produknya, bahwa konsumen menginginkan lingkungan yang aman dan sehat sebagai hal yang penting dan menjadi pertimbangan mereka dalam membeli suatu produk. Tujuan ekologis dalam perencanaaan produk adalah mengurangi konsumsi sumber daya dan polusi, meningkatkan konservasi sumber daya yang langka (Keller man, 1978 dalam Bukhari 2011).

Karakteristik dari produk hijau (ramah lingkungan) terbagi menjadi dua kelas utama :

a. Berkaitan dengan dampak sosial dan dampak lingkungan dari produk/jasa tersebut. Dari sudut pandang produk ramah lingkungan adalah bagimana produk tersebut setelah dikonsumsi, apakah sampah / limbah tersebut memiliki kontribusi positif / negatif terhadap lingkungan

b. Berkaitan dengan proses produksinya. Bahwa sebuah produk terdiri dari wujud produk itu sendiri (contoh kemasannya) dan produk tambahan berupa layanan / jasa dari produk tersebut), semuanya menghasilkan produk secara keseluruhan (total produk). Mengingat karakteristik dari total produk dalam pemasaran hijau menjadikan perusahaan dapat mengaplikasikan konsep 5R (repair, reconditioning, reuse, recycling, remanufacture) berguna untuk meningkatkan kinerja lingkungan akibat dari pembuangan produk yang telah digunakan

Menurut Shaik, et.al (2016 : 483), produk ramah lingkungan harus memuaskan bagi konsumen ditinjau dari aspek :

a. Customer satisfaction : bahwa produk yang dihasilkan harus mampu memuaskan kebutuhan konsumen, sehingga produk tersebut bisa bertahan untuk jangka panjang

b. Dual focus : keduanya harus mampu focus pada aspek signifikansi ekologi dan sosial

c. Life - cycle orientation : sebuah produk hijau dibuat dengan janji bahwa tidak membahayakan lingkungan selama proses produksinya, penggunaan bahan baku sampai limbah yang dihasilkan

d. Significant improvement : produk hijau disyaratkan untuk dapat mengatasi masalah sosio-ekologi di tingkat global dan memberikan peningkatan kinerja produk yang berkelanjutan

e. Continuous improvement : produk yang dihasilkan harus bertujuan pada pengembangan berkelanjutan, selaras dengan perkembangan sosial, teknologi dan perubahan lingkungan

2. Harga

Mengacu pada harga yang ditentukan berdasarkan kebijakan perusahaan dengan memperhatikan aturan dan kebijakan mengenai lingkungan yang diberlakukan oleh 
perusahaan. Harga adalah faktor yang penting dan kritis terkait bauran pemasaran hijau. Kebanyakan konsumen hanya mau membayar lebih bila mereka mempersepsikan nilai tambah dari produk yang dibeli. Nilai ini terkait dengan pengembangan kinerja, fungsi, desain ataupun daya tarik visual. Menurut Akter (2012) dalam Panjaitan (2014), bahwa produk ramah lingkungan memiliki harga premium sehingga calon konsumen selalu mempersepsikan bahwa produk ramah lingkungan memiliki harga yang tinggi. Meskipun hasil survey mengatakan bahwa konsumen bersedia membayar lebih tinggi untuk produk hijau yang akan mereka beli, namun terdapat juga perbedaan antara niat dengan perilaku yang nyata dilakukan oleh konsumen, bahwa mereka akhirnya tidak membeli produk hijau tersebut. Hal inlah yang harus diwaspadai oleh tenaga pemasar dan dievaluasi agar mendapatkan strategi yang tepat.

Harga jual produk hijau adalah sesuatu yang penting karena harga mencerminkan bagaimana produk tersebut terhadap lingkungan melalui perubahan penampilan, fungsionalitas dan customization. Harga jual produk hijau rata-rata lebih tinggi dibandingkan produk konvensional karena adanya modifikasi pada proses produksi, pada kemasannya ataupun pada proses pembuangannya.

3. Distribusi Hijau

Distribusi hijau adalah proses mengelola logistik sampai ke tangan konsumen dengan mengurangi pengiriman barang yang sangat jauh dari asal konsumen, sehingga bisa mengurangi biaya pengiriman dan yang terpenting adalah mengurangi emisi karbon, yang dihasilkan dari alat transportasi mulai dari moda transportasi darat, laut dan udara

Menurut Singh dan Pandey (2012:28) dalam Savitri, et.al (2016), "the choice of where and when to make a product available will have significant impact on the customers." Yang artinya bahwa pilihan untuk menempatkan dimana dan kapan suatu produk tersedia akan berdampak terhadap customer.

Menurut Abzari, et.al (2013) tindakan distribusi dan transportasi hijau adalah: 1. Mengembangkan metode distribusi terpusat, yang menciptakan keunggulan lingkungan melalui pengurangan pergerakan kendaraan (pengangkutan) dan pengurangan pengiriman.

2. Menyusun kebijakan yang sesuai untuk mengurangi polusi dari kendaraan yanmg digunakan untuk mengangkut barang.

3. Menganalisis biaya dan kegunaan dari proses daur ulang dan kemasan

4. Peningkatan kesadaran lingkungan baik perusahaan ataupun pihak lain yang terkait dengan proses transportasi

4. Promosi hijau

Promosi adalah komunikasi yang memberi informasi kepada calon konsumen mengenai suatu produk yang dapat memenuhi kebutuhan dan keinginan konsumen dan mendorong mereka untuk membeli (Alma, 2014: 301). Promosi hijau menyediakan informasi riil mengenai produk yang dijual dengan cara yang tidak melukai kepentingan konsumen.

Perilaku yang ditunjukkan oleh konsumen dalam melakukan pembelian suatu produk bisa diperngaruhi oleh dorongan psikologi. Diharapkan melalui pembelian produk tersebut konsumen terpenuhi kebutuhan fungsional, sosial dan psikologisnya (Siswanto: 2011)

Ada empat elemen promosi yang dikenal dengan bauran promosi, yaitu periklanan, penjualan pribadi, promosi penjualan dan publisitas

Menurut Bukhari (2011), terdapat tiga jenis promosi hijau, yaitu

1. Iklan yang menangani hubungan antara produk / jasa dan lingkungan

2. Mereka yang mempromosikan gaya hidup hijau dengan menyoroti produk atau layanan

3. Iklan yang menayangkan tanggung jawab lingkungan yang dilakukan oleh peusahaan 
Menurut Singh and Pandey (2012:28) dalam Savitri (2016), terdapat tiga jenis periklanan hijau :

1. Ads that address a relationship between a product/service and the biophysical environment (Iklan yang membahas hubungan antara produk atau jasa dengan lingkungan biofisik.)

2. Those that promote a green lifestyle by highlighting a product or service (Mempromosikan gaya hidup hijau dengan menyoroti suatu produk atau jasa)

3. Ads that present a corporate image ofenvironmental responsibility (Mengiklankan citra perusahaan dari tanggung jawab lingkungan)

\section{Konsumen Hijau}

Konsumen hijau adalah konsumen yang menghindari produk berbahaya bagi kesehatan dirinya dan orang lain, produk yang proses produksinya menyebabkan bahaya bagi lingkungan, produk yang diproduksi dengan menggunakan energi yang tidak proporsional, produk yang menghasilkan limbah yang tidak dapat terurai dan produk dengan penggunaan bahan baku yang berasal dari binatang atau tumbuhan yang hampir punah (Setiyaningrum, et.al, 2015: 311)

Baunmann, Boons, \& Bragd, 2002; Figueiredo \& Guillen, 2011:2 dalam Widodo, et.al : 2015, istilah "produk hijau" digunakan secara luas untuk menggambarkan produk yang mengintegrasikan persyaratan lingkungan dalam proses perancangan awal, termasuk meminimalkan bahan baku dan konsumsi energi, pembuangan limbah, risiko kesehatan dan keselamatan, dan degradasi ekologis.

\section{Perilaku Konsumsi Hijau (green consumption behaviour)}

Perilaku konsumsi hijau adalah perilaku yang dilakukan oleh konsumen hijau (green consumer) sebagai perwujudan tanggung jawabnya terhadap produk yang dikonsumsinya, sebagai bentuk kepedulian terhadap lingkungan dan menggunakan kemampuan membelinya untuk mengkampanyekan perubahan sosial dan lingkungan (Fraj \& Martinez. 2006; Webster, 1975: dalam Cruz dan Prabawani, 2017).

Berger, 1993 (dalam Siswanto:2012) mengatakan bahwa "Consumers have displayed a willingness to respond to green concerns whilst not compromising on performance, convenience, price, Health and safety":

1. Price atau harga, karena seringkali produk-produk ramah lingkungan memiliki harga yang lebih mahal daripada less-green product. Menurut penelitian sebelumnya yang dikutip dari Mandese, 1991 (dalam D’Souza, et. al., (2006) mengatakan bahwa "Pemasar juga menemukan bahwa konsumen adalah sensitif terhadap harga ketika datang untuk "membeli hijau" dan tidak mau membayar harga premium untuk produk hijau.

2. Performance atau kinerja beberapa produk-produk ramah lingkungan seperti produkproduk pembersih yang tidak menggunakan bahan-bahan kimia kurang memberikan hasil yang baik dibandingkan dengan produk sejenis namun memakai bahan-bahan kimia.

3. Convenience atau kenyamanan, produk-produk seperti makanan kaleng, makanan beku, memberikan kemudahan bagi konsumen untuk mengkonsumsinya. Banyak produkproduk ramah lingkungan tidak memberikan kemudahan seperti ini.

4. Health and Safety atau kesehatan dan keselamatan, secara umum produk-produk ramah lingkungan dibuat untuk menjaga kesehatan dan keselamatan manusia.

5. Availability atau ketersediaan, keterbatasan jumlah dari produk-produk ramah lingkungan dapat menyebabkan konsumen mencari substitusi lainnya. 


\section{Keputusan Pembelian}

Proses keputusan pembelian, seorang konsumen akan mempertimbangkan keputusannya sebelum akhirnya membeli. Tahapan dalam suatu proses keputusan pembelian, menurut Kotler dan Keller (2009 : 185) adalah

1. Pengenalan masalah : diawali dari kebutuhan konsumen terhadap produk tertentu yang berasal dari faktor internal dan eksternal

2. Pencarian informasi : setelah konsumen mengetahui apa yang dibutuhkna, maka konsumen akan mencari informasi terkait produk yang dibutuhkannya tersebut. Pembelian dilakukan jika sudah cukup informasi dan informasi tentang produk tersebut memuaskan

3. Evaluasi alternatif yang tersedia: proses pemilihan produk biasanya melibatkan lebih dari satu alternatif, Beberapa konsep dasar dari proses evaluasi konsumen adalah yang pertama konsumen berusaha memenuhi kebutuhan. Kedua, konsumen mencari manfaat tertentu dari solusi produk. Ketiga, konsumen memandang masing-masing produk sebagai kumpulan atribut dengan kemampuan yang berbeda-beda dalam memberikan manfaat yang digunakan untuk memuaskan kebutuhan itu.

4. Keputusan pembelian : dua faktor yang mempengaruhi niat pembeli dan keputusan pembelian, yaitu:

a) Sikap orang lain, sejauh mana sikap orang lain mengurangi alternatif yang disukai seseorang akan bergantung pada dua hal, yaitu intensitas sikap negatif orang terhadap alternatif yang disukai konsumen dan motivasi konsumen untuk menuruti keinginan orang lain.

b) Faktor situasi yang tidak terantisipasi yang dapat muncul dan dapat mengubah niat pembelian. Seperti pendapatan, keluarga, harga dan keuntungan dari produk tersebut.

5. Perilaku pasca pembelian : penilain terhadap produk dimulai setelah produk tersebut telah dikonsumsi. Akan ada beberapa kemungkinan seperti konsumen ragu-ragu, tidak puas dan puas terhadap produk tersebut. Faktor tersebut yang akan menjadi suatu keputusan dikemudian hari apakah pembelian akan dilakukan lagi pada merek tersebut ataukah akan berpindah pada merek lainnya

Menurut Alma (2011: 97), keputusan pembelian dipengaruhi oleh empat faktor, yaitu kebudayaan, kelas sosial, keluarga dan kelompok referensi ( $c l u b)$, sedangkan penelitian yang telah dilakukan oleh Savitri, et.al (2011) menunjukkan bahwa terdapat pengaruh signifikan antara kualitas produk hijau dan harga premium pada keputusan pembelian produk

\section{Kepuasan Konsumen}

Kepuasan konsumen adalah sikap terhadap hasil yang ditunjukkan oleh produk yang setelah dikonsumsi / dirasakan terhadap ekspektasi sebelumnya (Kotler dan Keller, 2007: 177). Hasil ini akan mempengaruhi pemikiran terhadap produk tersebut selanjutnya, baik positif ataupun negatif.

Menurut Irawan (2004:37), faktor - faktor pendorong kepuasan pelanggan adalah :

1. Kualitas produk. Kepuasan pelanggan ditentukan oleh kualitas produk yang dikonsumsi

2. Harga. Bergantung siapa konsumennya, bagi konsumen yang peka terhadap harga maka mereka akan cenderung mencari produk yang lebih murah agar mendapatkan value for money yang tinggi.

3. Kualitas pelayanan. Kualitas pelayanan merupakan penggerak kepuasan pelanggan.

4. Faktor emosional. Bahwa pelanggan terpuaskan dengan factor emosional yang mampu diberikan oleh merek tertentu.

5. Biaya dan kemudahan. Pelanggan akan puas bila produk itu memiliki efisiensi, kenyamanan dan kemudahan 
Penelitian yang dilakukan oleh Savitri, dkk (2016) menjelaskan bahwa harga premium berpengaruh positif dan signifikan terhadap keputusan pembelian, kualitas produk hijau positif dan signifikan terhadap kepuasan konsumen, harga premium berpengaruh positif dan signifikan terhadap kepuasan konsumen, keputusan pembelian berpengaruh positif dan signifikan terhadap kepuasan konsumen

\section{Hubungan Antar Variabel}

\section{Pengaruh Promosi Hijau Terhadap Keputusan Pembelian}

Hasil penelitian Nugraha, A.P (2015) menunjukkan bahwa terpaan iklan hijau di televisi berpengaruh positif dan signifikan terhadap minat konsumsi air minum dalam kemasan (AMDK) merek Ades pada komunitas atlet di Kota Semarang. Pengetahuan tentang manfaat air putih berpengaruh positif dan signifikan terhadap minat konsumsi air minum dalam kemasan (AMDK) merek Ades pada komunitas atlet di Kota Semarang

Berdasarkan hasil penelitian Nursanty dan Melisa (2011), variabel green advertising memiliki pengaruh secara langsung dan tidak langsung terhadap keputusan pembelian. Artinya bahwa sebuah iklan sangat mempengaruhi konsumen dalam memutuskan untuk membeli suatu produk. Hal tersebut sesuai dengan teori green advertising yang menyatakan bahwa setiap iklan secara eksplisit maupun implisit menunjukkan hubungan antara produk dan lingkungan biofisik, sehingga harus memiliki karakteristik mampu mempromosikan gaya hidup yang hijau dan meningkatkan sebuah citra tanggung jawab sosial perusahaan. Dapat disimpulkan dari penelitian tersebut bahwa keputusan pembelian dapat tercipta karena adanya pengaruh kuat dari ciri iklan yang ramah lingkungan, namun demikian keputusan pembelian juga harus melalui pemilihan akan produk sebagai mediator terlebih dahulu.

Berdasarkan uraian di atas, maka hipotesis yang diajukan dalam penelitian ini adalah :

H1 : Promosi hijau berpengaruh terhadap keputusan pembelian

\section{Pengaruh Harga Produk Hijau Terhadap Keputusan Pembelian}

Keputusan konsumen untuk membeli suatu produk dilandasi atas harga yang ditawarkan oleh produsen. Kesediaan konsumen untuk membeli suatu produk didasari atas pertimbangan bahwa konsumen akan mendapatkan manfaat dari produk yang dikonsumsinya. Bahwa harga yang dibayarkan oleh konsumen sebanding atau bahkan diatas dari harapan konsumen, dan mampu memberikan kepuasan bagi konsumen. Harga yang tinggi diharapkan diimbangi dengan kualitas, fitur dan keunggulan produk, sehingga konsumen rela membayar dengan harga tinggi atas keunggulan yang dimiliki oleh produk tersebut dan menjadi konsumen yang memiliki loyalitas. Penelitian yang dilakukan oleh Savitri, dkk (2016) menjelaskan bahwa harga premium berpengaruh positif dan signifikan terhadap keputusan pembelian, dan keputusan pembelian berpengaruh positif dan signifikan terhadap kepuasan konsumen

Berdasarkan uraian di atas, maka hipotesis yang diajukan dalam penelitian ini adalah :

$\mathrm{H} 2$ : Harga produk hijau berpengaruh terhadap keputusan pembelian

\section{Keputusan Pembelian sebagai Pemediasi Promosi Hijau terhadap Kepuasan konsumen.}

Keputusan pembelian suatu produk yang tepat sangat berperan dalam penetuan kepuasan konsumen akibat dari manfaat dan kualitas yang dirasakan. Hal ini logis mengingat konsumen belum akan puas terhadap suatu produk apabila konsumen tersebut tidak melakukan pembelian. Penelitian yang dilakukan oleh Savitri, dkk (2016) menunjukkan bahwa keputusan pembelian sebagai variabel intervening antara kualitas dan harga produk hijau terhadap kepuasan konsumen. Isliko (2010) dalam penelitiannya mendapatkan hasil bahwa keputusan pembelian berpengaruh terhadap kepuasan konsumen. Kepuasan pembelian dibangun oleh keputusan pembelian yang tepat.

Berdasarkan uraian di atas, maka hipotesis yang diajukan dalam penelitian ini adalah : 
H3 : Pengaruh promosi hijau terhadap kepuasan konsumen dimediasi oleh keputusan pembelian

Pengaruh harga hijau terhadap kepuasan konsumen dimediasi oleh keputusan pembelian

Salah satu aspek yang dilihat oleh konsumen dalam membeli suatu produk adalah harga. Harga menjadi daya tarik sendiri bagi konsumen, sehingga produsen harus jeli dalam melihat posisi harga yang diberikan kepada konsumen. Dalam menetapkan harga jual, produsen harus memperhatikan pesaing, daya beli konsumen, aturan dari pemerintah dan juga jangka waktu perputaran dana. Tinggi rendahnya minat beli ditentukan oleh harga yang ditawarkan produsen kepada konsumen. Terciptanya kepuasan konsumen atas pembelian tentu saja ketika harapan konsumen mampu diberikan oleh produsen.

Hasil penelitian Savitri (2016) menunjukkan bahwa keputusan pembelian terbukti sebagai variabel intervening dalam hubungan antara harga premium (X2) dengan kepuasan konsumen (Y).

Berdasarkan uraian di atas, maka hipotesis yang diajukan dalam penelitian ini adalah :

H4 : Pengaruh harga hijau terhadap kepuasan konsumen dimediasi oleh keputusan pembelian

\section{Pengaruh Keputusan Pembelian Terhadap Kepuasan Konsumen}

Kepuasan yang konsumen dapatkan setelah membeli suatu produk dapat berasal dari kuallitas, fungsi, harga, daya tahan produk yang melebihi ekspektasi konsumen. Dalam jurnal terdahulu, penelitian yang dilakukan oleh Savitri, dkk (2016) mendapatkan hasil bahwa keputusan pembelian berpengaruh terhadap kepuasan konsumen. Penelitian lainnya yang mendukung temuan tersebut dilakukan oleh Isliko (2008), bahwa keputusan pembelian berpengaruh terhadap kepuasan konsumen.

Berdasarkan uraian di atas, maka hipotesis yang diajukan dalam penelitian ini adalah :

H5 : Keputusan pembelian berpengaruh terhadap kepuasan konsumen

\section{METODE PENELITIAN}

\section{Proses Pengumpulan Data}

Prosedur pengumpulan data dalam penelitian ini menggunakan prosedur pengumpulan data primer dan data sekunder. Data primer adalah data yang diperoleh secara langsung dari sumber penelitian (dalam hal ini adalah responden) yaitu melalui pengisian kuisioner kepada responden. Data sekunder adalah data yang telah dikumpulkan oleh pihak lain, sehingga peneliti merupakan pihak kedua yang memanfaatkan data yang telah dikumpulkan oleh pihak pertama sebelumnya. Pada penelitian ini data sekunder diperoleh dari informasi dan data yang berasal buku, literatur-literatur, website dan jurnal-jurnal yang dipublikasikan.

Instrumen yang digunakan dalam penelitian ini adalah kuisioner dengan pengukuran data interval. Penggunaan kuisioner memiliki kelebihan yaitu lebih rendah biaya yang dikeluarkan dan dapat menghemat tenaga dan waktu. Kuesioner tersebut diolah dengan menggunakan jenis skala ordinal dan skala pengukurannya menggunakan skala likert. Skala Likert digunakan untuk mengukur sikap, pendapat, dan persepsi seseorang atau sekelompok orang tentang fenomena sosial. Dalam penelitian, fenomena sosial ini telah ditetapkan secara spesifik oleh peneliti, yang selanjutnya disebut sebagai variabel penelitian (Sugiyono, 2011:93).

Pengambilan sampel dilakukan dengan teknik nonprobability sampling, yaitu teknik pengambilan sampel yang tidak memberi peluang/kesempatan sama bagi setiap unsur atau anggota populasi untuk dipilih menjadi sampel. Karena jumlah populasi tidak diketahui, sampel diambil dengan metode accidental sampling yaitu teknik penentuan sampel berdasarkan kebetulan yaitu siapa saja yang secara kebetulan bertemu dengan peneliti dapat digunakan sebagai sampel, bila dipandang orang yang kebetulan ditemui itu cocok sebagai sumber data, 
Menurut Ferdinand (2006: 173), dalam penelitian multivariate (termasuk yang menggunakan analisis regresi multivariate) besarnya sampel ditentukan sebanyak 25 kali independen. Menurut Roscoe (1975) dalam Ferdinand (2006: 173) pedoman umum untuk menentukan besarnya sampel peneltian, yaitu ukuran sampel berkisar 30 - 500 memadai untuk suatu penelitian. Dalam penelitian ini jumlah variabel independen adalah 2 variabel, sehingga jumlah sampel 50 responden atau lebih. Sampel pada penelitian ini adalah mahasiswa STIESIA Surabaya dimana kuisioner akan dibagikan pada beberapa titik di lingkungan STIESIA Surabaya, yaitu pengunjung Galeri Investasi BEI, mahasiswa yang mengikuti perkuliahan peneliti pada periode yang ditentukan dan ruang Perpustakaan. Hal ini dilakukan untuk mempermudah penyebaran kuisioner dan pengembaliannya

\section{Metode dan Teknik Analisis}

Teknik analisis menurut Istijanto (2008:157) merupakan tindakan mengolah data menjadi informasi yang bermanfaat untuk menjawab masalah penelitian. Pada tahap ini, peneliti mengolah data yang sudah diinput pada tahap sebelumnya menjadi hasil keluaran atau output yaitu informasi. Teknik analisis yang digunakan dalam penelitian ini adalah teknik analisis data kuantitatif menggunakan pemodelan Path Analysis.

Penelitian ini menggunakan analisis jalur (path analysis). Menurut Ghozali, (2011: 174), "Analisis jalur merupakan perluasan dari analisis regresi linear berganda, atau analisis jalur adalah penggunaan analisis regresi untuk menaksir hubungan kausalitas antar variabel yang telah ditetapkan sebelumnya. Pengolahan analisis jalur menggunakan bantuan analisis regresi. Analisis regresi merupakan studi mengenai ketergantungan variabel dependen dengan salah satu atau lebih variabel independen, dengan tujuan untuk mengestimasi rata-rata populasi atau nilai rata-rata variabel dependen berdasarkan nilai variabel independen yang diketahui (Ghozali, 2007: 85). Hasil dari analisis regresi adalah berupa koefisien untuk masing-masing variabel independen. Koefisien ini diperoleh dengan cara memprediksi nilai variabel dependen dengan suatu persamaan. Koefisien regresi dihitung dengan dua tujuan sekaligus, yaitu meminimumkan penyimpangan antara nilai aktual dan nilai estimasi variabel dependen berdasarkan data yang ada.

Kriteria pengambilan keputusan:

Ho diterima jika Fhitung < Ftabel pada $\alpha=5 \%$ dan signifikansi $\mathrm{F}$ hitung lebih besar dari 0,05 Ha diterima jika Fhitung > Ftabel pada $\alpha=5 \%$ dan signifikansi F hitung lebih kecil dari 0,05.

Sebelum disebarkan kepada responden, kuisioner harus diuji terlebih dahulu variabilitasnya dan reliabilitasnya. Menurut Sumarsono (2004: 291), pengujian validitas dilakukan untuk menguji apakah data yang diperoleh mampu mengukur dan mengungkap data dari variabel yang dipilih secara tepat. Tinggi rendahnya validitas menunjukkan sejauh mana data yang terkumpul tidak menyimpang dari gambaran tentang variabel yang dimaksud. Reliabilitas adalah cara untuk menguji sejauh mana hasil suatu pengukuran dapat dipercaya. Alat ukur memiliki reliabilitas yang tinggi jika dalam beberapa kali pelaksanaan pengukuran terhadap kelompok subjek yang sama diperoleh hasil yang relatif sama, selama aspek yang diukur dalam diri subjek memang belum berubah.

\section{PEMBAHASAN}

\section{Pengujian Kualitas Data}

1. Pengujian Validitas

Validitas adalah suatu derajat ketepatan alat ukur penelitian tentang isi sebenarnya yang diukur. Analisis validitas item bertujuan untuk menguji apakah tiap butir pertanyaan benar-benar telah sah, kita dapat menetapkan derajat yang tinggi dari kedekatan data yang diperoleh dengan apa yang kita yakini dalam pengukurannya. Sebagai alat ukur yang 
digunakan, analisis ini dilakukan dengan cara mengkorelasikan antara skor item dengan skor total item. Hasil uji validitas sebagai berikut:

Tabel 4

Hasil Uji Validitas Instrumen Variabel Promosi

\begin{tabular}{|c|c|c|c|}
\hline Indikator & $\boldsymbol{r}$ hitung & $\boldsymbol{r}$ table & Keterangan \\
\hline PR 1 & 0,830 & 0,081 & Valid \\
\hline PR 2 & 0,735 & 0,081 & Valid \\
\hline PR 3 & 0,660 & 0,081 & Valid \\
\hline \multicolumn{3}{|c|}{ Sumber: data diolah }
\end{tabular}

Berdasarkan hasil uji validitas variabel promosi, terlihat bahwa nilai Corrected Item-Total Correlation > 0,081, maka butir pernyataan dikatakan valid.

Tabel 5

Hasil Uji Validitas Instrumen Variabel Harga

\begin{tabular}{|c|c|c|c|}
\hline Indikator & $\boldsymbol{r}$ hitung & $\boldsymbol{r}$ table & Keterangan \\
\hline HRG 1 & 0,685 & 0,081 & Valid \\
\hline HRG 2 & 0,641 & 0,081 & Valid \\
\hline HRG 3 & 0,581 & 0,081 & Valid \\
\hline HRG 4 & 0,675 & 0,081 & Valid \\
\hline \multicolumn{4}{|c|}{ Sumber: data diolah } \\
\hline
\end{tabular}

Berdasarkan hasil uji validitas variabel harga, terlihat bahwa nilai Corrected Item-Total Correlation > 0,081, maka butir pernyataan dikatakan valid.

Tabel 6

Hasil Uji Validitas Instrumen Variabel Keputusan Pembelian

\begin{tabular}{|c|c|c|c|}
\hline Indikator & $\boldsymbol{r}$ hitung & $\boldsymbol{r}$ table & Keterangan \\
\hline KPT 1 & 0,750 & 0,081 & Valid \\
\hline KPT 2 & 0,770 & 0,081 & Valid \\
\hline KPT 3 & 0,705 & 0,081 & Valid \\
\hline
\end{tabular}

Sumber: data diolah

Berdasarkan hasil uji validitas variabel keputusan pembelian, terlihat bahwa nilai Corrected Item-Total Correlation > 0,081, maka butir pernyataan dikatakan valid.

Tabel 7

Hasil Uji Validitas Instrumen Variabel Kepuasan Konsumen

\begin{tabular}{|c|c|c|c|}
\hline Indikator & $\boldsymbol{r}$ hitung & $\boldsymbol{r}$ table & Keterangan \\
\hline KEP 1 & 0,769 & 0,081 & Valid \\
\hline KEP 2 & 0,754 & 0,081 & Valid \\
\hline KEP 3 & 0,651 & 0,081 & Valid \\
\hline \multicolumn{3}{|c|}{ Sumber: data diolah }
\end{tabular}


Berdasarkan hasil uji validitas variabel kepuasan konsumen, terlihat bahwa nilai Corrected Item-Total Correlation > 0,081, maka butir pernyataan dikatakan valid.

2. Pengujian Reliabilitas

Reliabilitas adalah cara untuk menguji sejauh mana hasil suatu pengukuran dapat dipercaya. Alat ukur memiliki reliabilitas yang tinggi jika dalam beberapa kali pelaksanaan pengukuran terhadap kelompok subjek yang sama diperoleh hasil yang relatif sama, selama aspek yang diukur dalam diri subjek memang belum berubah (Sugiono, 2007:75).

Tabel 8

Hasil Perhitungan Uji Reliabilitas Instrumen

\begin{tabular}{|r|c|r|c|c|}
\hline \multicolumn{1}{|c|}{$\mathbf{N}$} & Variabel & $\begin{array}{r}\text { Cronba } \\
\text { ch's Alpha }\end{array}$ & $\begin{array}{c}\text { Minimal Cronbach's } \\
\text { Alpha yang } \\
\text { disyaratkan }\end{array}$ & $\begin{array}{c}\text { Keteran } \\
\text { gan }\end{array}$ \\
\hline 1 & Promosi & 0,695 & 0,60 & Reliabel \\
\hline 2 & Harga & 0,630 & 0,60 & Reliabel \\
\hline 3 & $\begin{array}{c}\text { Keputusan } \\
\text { Pembelian }\end{array}$ & 0,692 & 0,60 & Reliabel \\
\hline 4 & $\begin{array}{c}\text { Kepuasaan } \\
\text { Konsumen }\end{array}$ & 0,643 & 0,60 & \\
\hline
\end{tabular}

Sumber: data diolah

Berdasarkan hasil uji reliabilitas yang telah dilakukan dapat diketahui bahwa hasil Cronbach's Alpha setiap variabel lebih dari standar minimal Cronbach's Alpha yang disyaratkan yaitu 0,60, maka variabel promosi, harga, keputusan pembelian dan kepuasan konsumen adalah reliabel.

\section{Analisis Path}

1. Pengujian Normalitas

Pengujian normalitas dilakukan dengan melihat nilai Kurtosis Value dari data yang digunakan. Nilai statistik untuk menguji normalitas disebut $z$-value. Bila nilai-z kurang dari nilai kritis maka dapat diduga bahwa distribusi data adalah normal. Hasil pengujian normalitas tampak pada Tabel berikut:

Tabel 9

Hasil Uji Normalitas

\begin{tabular}{|c|c|c|c|c|}
\hline Variabel & Minimum & Maximum & Kurtosis & c.r. \\
\hline HRG & 2.000 & 5.000 & .001 & .003 \\
PR & 2.000 & 5.000 & 1.415 & 2.356 \\
KPT & 2.330 & 5.000 & -0.766 & -1.817 \\
KEP & 2.670 & 5.000 & -0.842 & -1.996 \\
Multivariate & & & 4.351 & 2.487 \\
\hline Batas Normal & & $\pm 2,57$ \\
\hline
\end{tabular}

Sumber: data diolah 
Nilai kritis dapat ditentukan berdasarkan tingkat signifikansi $0,05(5 \%)$ yaitu sebesar $\pm 2,57$. Hasilnya diperoleh nilai c.r. multivariat dan univariate di antara $\pm 2,57$ berarti asumsi normalitas terpenuhi.

2. Pengujian Outlier

Outlier adalah observasi atau data yang memiliki karakteristik unik yang terlihat sangat berbeda jauh dari observasi-observasi lainnya dan muncul dalam bentuk nilai ekstrim untuk sebuah variabel tunggal atau variabel kombinasi atau mutivariat (Hair et al, 2008). Deteksi terhadap multivariat outlier dilakukan dengan menggunakan kriteria Jarak Mahalanobis pada tingkat $\mathrm{p}<0,05$. Jarak Mahalanobis itu di evaluasi dengan menggunakan $\chi^{2}$ pada derajat bebas sebesar jumlah variabel yang digunakan dalam penelitian. Bila kasus yang mempunyai Jarak Mahalanobis lebih besar dari nilai chi-square pada tingkat signifikansi 0,05 maka terjadi multivariate outlier. Pada penelitian ini nilai $\chi^{2}{ }_{0.05}$ dengan jumlah variabel 4 adalah sebesar 9,488. Hasil analisis Mahalanobis diperoleh 8,765 nilai yang kurang dari $\chi^{2}$ sebesar 9,488, dengan demikian tidak terjadi multivariate outliers.

3. Pengujian Goodness of Fit Indice

Hasil pengujian goodness of fit indice tampak pada Tabel berikut:

\section{Tabel 10}

Hasil Uji Goodness of Fit Indice

\begin{tabular}{|c|c|c|c|c|}
\hline $\begin{array}{c}\text { Goodness of } \\
\text { Index }\end{array}$ & $\begin{array}{c}\text { Nilai } \\
\text { Kritis }\end{array}$ & $>/<$ & Hasil & Keterangan \\
\hline Probability & $\geq 0,05$ & $>$ & 0,072 & Baik \\
RMSEA & $\leq 0,08$ & $<$ & 0,072 & Baik \\
GFI & $\geq 0,90$ & $>$ & 0,950 & Baik \\
AGFI & $\geq 0,90$ & $>$ & 0,932 & Baik \\
CMIND/DF & $\leq 2,00$ & $<$ & 1,982 & Baik \\
TLI & $\geq 0,95$ & $<$ & 0,981 & Baik \\
CFI & $\geq 0,94$ & $<$ & 0,990 & Baik \\
\hline
\end{tabular}

Sumber: data diolah

Dari hasil evaluasi terhadap model one step approach modifikasi ternyata dari semua kriteria goodness of fit yang digunakan, tidak seluruhnya menunjukkan hasil evaluasi model yang baik, hal ini tidak mengapa bahwa model telah sesuai dengan data. Artinya, model konseptual yang dikembangkan dan dilandasi oleh teori telah sepenuhnya didukung oleh fakta. Dengan demikian model ini adalah model yang terbaik untuk menjelaskan keterkaitan antar variabel dalam model.

\section{Pengujian Hipotesis}

Proses pengolahan data dalam penelitian ini menggunakan program AMOS 18.01. Pada Tabel 11 berikut ini akan ditunjukkan hasil dari masing-masing variabel. 
Tabel 11

Hasil Penelitian

\begin{tabular}{|c|c|c|c|}
\hline Keterangan & $\begin{array}{c}\text { Std } \\
\text { Estimate }\end{array}$ & Signifikan & Keterangan \\
\hline Promosi $\rightarrow$ Keputusan Pembelian & 0,413 & 0,000 & Signifikan \\
Harga $\rightarrow$ Keputusan Pembelian & 0,222 & 0,005 & Signifikan \\
Keputusan Pembelian $\rightarrow$ Kepuasan & 0,591 & 0,000 & Signifikan \\
Konsumen & & & \\
\hline
\end{tabular}

\section{Sumber: data diolah}

\section{Hasil pengujian hipotesis kausalitas dapat dilihat dalam Tabel 11, dapat diaplikasikan sebagai berikut:}

1. Hipotesis kesatu menduga terdapat pengaruh promosi terhadap keputusan pembelian. Setelah dilakukan pengujian menunjukkan nilai standart estimate sebesar 0,413 dan probability sebesar 0,000 < level of significant 0,05 yang digunakan, maka dapat disimpulkan bahwa promosi memiliki pengaruh secara signifikan terhadap keputusan pembelian produk hijau. Hasil penelitian ini mendukung penelitian yang dilakukan oleh Nursanty dan Melisa (2011), yang meneliti pengaruh green advertising terhadap keputusan pembelian. Pada penelitian tersebut diperoleh hasil bahwa green advertising yang berwawasan lingkungan memiliki pengaruh langsung terhadap keputusan pembelian. Dapat disimpulkan dari penelitian tersebut bahwa keputusan pembelian dapat tercipta karena adanya pengaruh kuat dari ciri iklan yang ramah lingkungan.

2. Hipotesis kedua penelitian ini menduga terdapat pengaruh harga terhadap keputusan pembelian. Setelah dilakukan pengujian menunjukkan nilai standart estimate sebesar 0,222 dan probability sebesar 0,005 < level of significant 0,05 yang digunakan, maka dapat disimpulkan bahwa harga memiliki pengaruh secara signifikan terhadap keputusan pembelian pada produk hijau. Hasil penelitian ini mendukung penelitian yang dilakukan oleh Savitri (2016) yang menyebutkan bahwa harga premium berpengaruh positif terhadap keputusan pembelian.

3. Hipotesis penelitian ini menduga terdapat pengaruh keputusan pembelian terhadap kepuasan konsumen. Setelah dilakukan pengujian menunjukkan nilai standart estimate sebesar 0,591 dan probability sebesar $0,000<$ level of significant 0,05 yang digunakan, maka dapat disimpulkan bahwa keputusan pembelian memiliki pengaruh secara signifikan terhadap kepuasan konsumen pada produk hijau. Hasil penelitian ini mendukung penelitian yang dilakukan oleh Isliko (2010). Dalam penelitian Isliko (2010) diperoleh hasil bahwa keputusan pembelian berpengaruh terhadap kepuasan konsumen. Kepuasan pembelian dibangun oleh keputusan pembelian yang tepat.

\section{Pengaruh Tidak Langsung}

Pengaruh tidak langsung adalah pengaruh antar variabel melalui variabel lain. Berdasarkan kerangka berpikir yang termasuk pengaruh tidak langsung adalah pengaruh promosi terhadap kepuasan konsumen melalui keputusan pembelian. Serta pengaruh harga terhadap kepuasan konsumen melalui keputusan pembelian. Tabel yang digunakan untuk menganalisa pengaruh tidak langsung adalah hasil dari Tabel Standardized Indirect Effect. Hasil dari Tabel Standardized Indirect Effect dapat dilihat pada Tabel 12: 
Tabel 12

Hasil Pengaruh Tidak Langsung

\begin{tabular}{|ccccc|c|}
\hline \multicolumn{5}{|c|}{ Jalur } & Estimate \\
\hline Promosi & $\rightarrow$ & Keputusan Pembelian & $\rightarrow$ & Kepuasan Konsumen & 0,245 \\
\hline Harga $\rightarrow$ & Keputusan Pembelian $\rightarrow$ & Kepuasan Konsumen & 0,132 \\
\hline
\end{tabular}

Sumber: data diolah

Hasil pengujian menunjukkan bahwa :

1. Pengaruh tidak langsung dari promosi terhadap kepuasan konsumen melalui keputusan pembelian sebesar 0,245 atau $24,5 \%$. Hipotesis yang menyebutkan bahwa diduga terdapat pengaruh promosi hijau terhadap kepuasan konsumen yang dimediasi oleh keputusan pembelian, diterima. Hasil penelitian ini mendukung penelitian yang dilakukan oleh Isliko (2010). Dalam penelitiannya mendapatkan hasil bahwa keputusan pembelian berpengaruh terhadap kepuasan konsumen. Kepuasan pembelian dibangun oleh keputusan pembelian yang tepat.

2. Pengaruh tidak langsung dari harga terhadap kepuasan konsumen melalui keputusan pembelian sebesar 0,132 atau 13,2\%. Hipotesis yang menyebutkan bahwa diduga terdapat pengaruh harga hijau terhadap kepuasan konsumen yang dimediasi oleh keputusan pembelian, diterima. Hasil penelitian ini mendukung penelitian yang dilakukan oleh Savitri (2016) yaitu keputusan pembelian terbukti sebagai variabel intervening dalam hubungan antara harga premium (X2) dengan kepuasan konsumen (Y). Hal ini membuktikan bahwa, harga yang ditawarkan oleh produk hijau mampu meningkatkan keputusan pembelian konsumen pada produk hijau.

\section{PENUTUP}

Berdasarkan hipotesis dan hasil penelitian, maka simpulan dalam penelitian ini adalah sebagai berikut:

1. Hipotesis pertama yang menyatakan bahwa promosi hijau berpengaruh terhadap keputusan pembelian diterima. Hasil penelitian menunjukkan bahwa promosi hijau berpengaruh positif terhadap keputusan pembelian

2. Hipotesis kedua yang menyatakan bahwa harga produk hijau berpengaruh terhadap keputusan pembelian diterima. Hasil penelitian menunjukkan bahwa harga produk hijau berpengaruh positif terhadap keputusan pembelian

3. Hipotesis ketiga yang menyatakan bahwa pengaruh promosi hijau terhadap kepuasan konsumen dimediasi oleh keputusan pembelian. Hasil penelitian menunjukkan bahwa terdapat pengaruh promosi terhadap kepuasan konsumen melalui keputusan pembelian sebesar $24.5 \%$

4. Hipotesis keempat yang menyatakan bahwa pengaruh promosi hijau terhadap kepuasan konsumen dimediasi oleh keputusan pembelian. Hasil penelitian menunjukkan bahwa terdapat pengaruh harga terhadap kepuasan konsumen melalui keputusan pembelian sebesar $13.2 \%$

5. Hipotesis kelima yang menyatakan bahwa keputusan pembelian berpengaruh terhadap kepuasan konsumen diterima. Hasil penelitian menunjukkan bahwa keputusan pembelian berpengaruh positif terhadap kepuasan konsumen

Dari hasil penelitian ini terdapat beberapa keterbatasan, yaitu penelitian hanya dilakukan pada satu perguruan tinggi saja, sehingga hasil yang berbeda mungkin saja akan diperoleh jika dilakukan penelitian pada perguruan tinggi lain. Sehingga untuk penelitian selanjutnya 
diharapkan dapat memperluas cakupan penelitian pada perguruan tinggi lain agar diperoleh hasil yang bervariasi.

Penelitian selanjutnya dapat menambahkan variabel seperti karakteristik demografi dan bauran pemasaran hijau lainnya untuk melihat pengaruh pemasaran hijau terhadap keputusan pembelian dan juga kepuasan konsumen.

\section{REFERENSI}

Abzari, M., Shad, S.F, A.A.A, Sharbiyani dan A.P. Morad. (2013). Studying the effect of green marketing mix on market share increase, European Online Journal of Natural and Social Sciences, vol. 2, no.3

Affandy, S. Konsumen Hijau: Ideologi dan Gerakan Konsumen Peduli Lingkungan, diunduh tanggal 15 November 2017/ www. bpkn.go.id,

Alma, B. (2014). Manajemen Pemasaran dan Pemasaran Jasa. Edisi Revisi. Bandung : Alfabeta.

Anonim. www.hijauku.com, 13 July 2011

Bukhari. (2011). Green Marketing and Its Impact on Consumer Behavior. European Journal of Business and Management, Vol 3, No.4

Cruz, M.U.A dan B. Prabawani. (2017). Konsumen Ramah Lingkungan : Perilaku Konsumsi Hijau Civitas Academika Universitas Diponegoro. Jurnal Ilmu Administrasi Bisnis, Vol. 6 no. 4. 2017, Pp. 40-50

Gozali, Imam. (2009). Aplikasi Analisis Multivariate dengan SPSS. Semarang: Badan Penerbit Universitas Diponegoro.

Ferdinand, A. (2006). Metode Penelitian Manajemen : Pedoman Penelitian untuk Penulisan Tesis dan Disertasi Ilmu Manajemen, Edisi kelima, Semarang, Undip Press

Fonseca, J.C.G. (2015). The Impact of Green Marketing Practices on Consumer Buying Decision, Master Dissertation in Business Administration, University Institute of Lisbon.

Hiqmah, F. (2017). Observasi Tren Perilaku Pembelian Hijau Konsumen Indonesia di Berbagai Industri, Journal of Business and Banking, vol. 6 no. 1, pp. 27-44

Hashem and Al Rifai. (2011). The influence of applying green marketing mix by chemical industries companies in three Arab States in West Asia on consumer's mental image, International Journal of Business and Social Science, Vol. 2 No. 3

Isliko, Thom W.A \& Mintarti Rahayu. (2010). Mediasi Keputusan Pembelian pada Pengaruh Situasional dan Faktor Produk terhadap Kepuasan Konsumen Supermarket di Kota Kupang. Jurnal Aplikasi Manajemen, Vol.8No.2, Mei 2010, 480-492

Istijanto. (2008). Riset Sumber Daya Manusia. Jakarta: PT. Gramedia Pustaka Utama.

Junior, B.A. (2012). Pengaruh Gaya Hidup Terhadap Keputusan Pembelian (Survey Terhadap Konsumen Green Product Pada Komunitas Green Di Kota Bandung). www.repository.upi.edu

Kotler P. dan K.L, Keller. (2009). Manajemen Pemasaran. Jilid 2. Edisi 13. Terjemahan. Jakarta: Pernerbit Erlangga. 
Novel, B.. (2015). Analisis Variabel-Variabel yang Mempengaruhi Keputusan Pembelian Konsumen Kopi Luwak di Kota Semarang. Skripsi. Universitas Diponegoro.

Nugraha, A.P. (2015). Pengaruh Terpaan Iklan Hijau di Televisi dan Pengetahuan tentang Manfaat Air Putih terhadap Minat Konsumsi Air Minum Dalam Kemasan (AMDK) Merek Ades pada Komunitas Atlet di Kota Semarang. Skripsi. Universitas Diponegoro

Nursanty, T.D, dan Melisa. (2011). Analisis Pengaruh Green Product dan Green Advertising Terhadap Keterlibatan Konsumen dan Dampaknya Pada Keputusan Pembelian Konsumen Laksmie Florist. Binus Business Review, Vol. 2 No. 2

Panjaitan, F.L.M. (2014). Pengaruh Green Marketing Terhadap Minat Beli Konsumen,(Studi Cluster Whelford di Bumi Serpong Damai). Skripsi. Universitas Indonesia

Siswanto, D.E. (2012) . Pengaruh Persepsi Konsumen pada Strategi Green Marketing Terhadap Sikap Konsumen pada Green Product. Skripsi. Universitas Muhammadiyah Surakarta

Setiyaningrum, Ari, Udaya, Jusuf dan Efendi. (2015). Prinsip-Prinsip Pemasaran, Plus Tren Terkini. Yogyakarta. Penerbit Andi.

Savitri, M.H, Suhariyono, Andriani Kusumawati, (2016). Pengaruh Kualitas Produk Hijau dan Harga Premium Terhadap Keputusan Pembelian dan Kepuasan Konsumen (Survei pada Konsumen Tupperware di Distributor Resmi PT Adicitra Prima Kencana Savitri, Jurnal Administrasi Bisnis (JAB), Vol. 40 No. 2 November 2016

Shaik, Shahazadi Begum, (2016). Handbook of Research on Green Economic Development Initiatives and Strategies. IGI Global: United States

Solaiman, Mohammad, Osman, Abdullah dan Mohd Suberi Bin Ab. Halim, Green Marketing: A Marketing Mix Point of View. (2015) International Journal of Business and Technopreneurship, vol.1, no.15

Sumarsono, H.M. Sonny. (2004). Metode Riset Sumber Daya Manusia. Edisi Pertama. Jogjakarta: Graha Ilmu

Widodo, A., Nurafni R dah T. Nandary. (2015). Factors Influencing Green Purchasing Behavior (Study on University Student in Bandung). GTAR Full Paper Proceeding, Vol. 2, 303313 